\title{
Penerapan Pendekatan Word and Paradigm pada Proses Morfofonemik Verba Bahasa Turki
}

\author{
An Application of the Word and Paradigm Approach to the Morphophonemic Process of \\ Turkish Verbs
}

\author{
Septiarini Makodamayanti ${ }^{1{ }^{1 *}}$ dan Agus Subiyanto ${ }^{2}$ \\ Fakultas Ilmu Budaya, Universitas Diponegoro, Semarang \\ ${ }^{1,{ }^{*}}$ Corresponding email: makodamaya18@gmail.com \\ ${ }^{2}$ Email: subaling@gmail.com
}

Received: 24 January 2021 Accepted: 01 July 2021 Published: 1 August 2021

\begin{abstract}
The Turkish language is one of the languages which people nowadays learn. The Turkish language belongs to agglutinative language with a slight border between words and their morpheme, yet it has a clear border amongst the morphemes. There is a vowel harmony in the Turkish language where the sound of the last vowel of the stem affects the vowel's sound of the attached suffixes. The existence of the vowel harmony triggers the change of the sound of the attached morphemes which their function is as suffixes. This study analyzes the morphophonemic process of Turkish verbs using the Word and Paradigm approach. The data of this study are the oral data of Turkish verbs got from the social media of YouTube. The data are collected by observing and noting. The morphophonemic process affected by the change of the sound is later analyzed using the padan method and Word and Paradigm or WP approach from the data collection. Through the approach, the wordformation rules are made for later, the effectiveness of the Word and Paradigm approach is studied in the morphophonemic analysis of Turkish verbs. The results show that there are different kinds of word-formation, and the WP approach effectively analyses Turkish verbs.
\end{abstract}

Keywords: morphophonemic, Turkish language, Word and Paradigm, morphology

\begin{abstract}
Abstrak: Bahasa Turki merupakan salah satu bahasa yang kini mulai banyak dipelajari. Bahasa Turki termasuk ke dalam bahasa bertipe aglutinatif di mana batas antara morfem dan kata sangat tipis namun antara morfem satu dengan yang lain dapat dibedakan dengan jelas. Dalam bahasa Turki terdapat harmonisasi vokal di mana bunyi vokal terakhir pada stem akan berpengaruh pada harmoni bunyi vokal pada sufiks yang menempel. Adanya harmoni vokal memicu perubahan bunyi pada morfem-morfem yang menempel yang berfungsi sebagai sufiks. Penelitian ini menganalisis proses morfofonemik verba bahasa Turki dengan pendekatan Word and Paradigm. Data pada penelitian ini merupakan data lisan yang berupa verba bahasa Turki yang diperoleh dari media sosial YouTube. Data dikumpulkan dengan teknik simak bebas libat cakap dan catat. Dari data yang diperoleh, proses morfofonemik yang dipengaruhi oleh adanya perubahan bunyi selanjutnya dianalisis menggunakan metode padan dengan pendekatan Word and Paradigm. Dengan pendekatan tersebut, kaidah pembentukan kata ditentukan untuk selanjutnya dikaji efektifitas pendekatan Word and Paradigm pada analisis morfofonemik verba bahasa Turki. Hasil penelitian menunjukkan bahwa dari tiga bentuk verba, yaitu infinitif, imperatif, dan perfektif, diperoleh kaidah pembentukan kata yang berbeda-beda. Selain itu, pendekatan Word and Paradigm diketahui efektif untuk mengkaji proses morfofonemik pada tiga bentuk verba dalam bahasa Turki.

Kata kunci: morfofonemik, bahasa Turki, Word and Paradigm, morfologi
\end{abstract}

To cite this article:

Makodamayanti, S., \& Subiyanto, A. (2021). Penerapan Pendekatan Word and Paradigm pada Proses Morfofonemik Verba Bahasa Turki. Diglosia: Jurnal Kajian Bahasa, Sastra, dan Pengajarannya, 4(3), 275-286. https://doi.org/10.30872/diglosia.v4i3.181 


\section{A. PENDAHULUAN}

Setiap bahasa memiliki keunikan, kekhasan, karakteristik, dan sifatnya masingmasing. Beberapa contohnya seperti bahasa Inggris yang dianggap sebagai bahasa yang sudah mapan berdasarkan strukturnya, atau bahasa Latin yang dianggap sangat kompleks karena hampir tidak ada batas antara morfem satu dengan lainnya. Selain itu, terdapat bahasa yang bersifat aglutinatif di mana antara kata dan morfemnya hampir menyatu seperti bahasa Turki. Sifat, ciri, ataupun tipe dari tiap-tiap bahasa seperti pada contoh sebelumnya, dapat dijadikan sebagai dasar untuk menganalisis masing-masing bahasa tersebut dengan menggunakan berbagai teori seperti morfologi, fonologi, semantik, maupun sintagmatis. Selanjutnya, dapat digunakan pendekatan tertentu berdasarkan satu dari beberapa teori yang dipilih untuk menganalisis lebih dalam bahasa yang akan digunakan sebagai objek kajian.

Meskipun bahasa Turki dianggap sebagai bahasa yang rumit karena sifatnya yang aglutinatif, namun bahasa Turki kini menjadi salah satu bahasa yang cukup banyak dipelajari baik oleh penutur bahasa Indonesia maupun penutur bahasa asing lainnya. Selain berlatar belakang akademis seperti adanya tuntutan penguasaan bahasa Turki untuk hal pendidikan bagi para pembelajar atau mahasiswa yang melanjutkan pendidikan ke negara Turki, adanya contoh fenomena seperti perkawinan campur antara warga negara Indonesia dengan warga negara Turki dewasa ini, turut melatarbelakangi dipelajarinya bahasa Turki oleh para penutur bahasa terutama bahasa Indonesia.

Terlepas dari latar belakang mengapa orang-orang tertarik mempelajari bahasa Turki, kembali pada sifat bahasanya yang aglutinatif, dalam bahasa Turki, sebuah kata dapat diikuti dua, tiga, atau lebih akhiran (Booij, 2005). Hal tersebut karena bahasa Turki hanya mengenal imbuhan yang berupa akhiran atau suffix. Setiap akhiran yang berupa morfem terikat berfungsi sebagai pemarkah di mana setiap pemarkah dapat terletak saling berurutan dan bersambungan satu sama lain. Demikian mengapa bahasa Turki termasuk dalam tipe bahasa aglutinatif (Yavuz \& Balc1, 2011) karena letak kata dan akhiran-akhirannya yang saling berurutan dan bersambungan satu dengan yang lain, menyebabkan hampir menyatunya antara kata dengan morfem-morfem yang ada.

Selain keunikan tersebut, terdapat ciri lain pada bahasa Turki, yaitu adanya harmonisasi vokal dimana vokal pertama pada akhiran bergantung pada vokal terakhir dari kata, root, atau stem yang dilekati (Lieber, 2009). Hal tersebut menyebabkan munculnya perubahan bunyi yang dipengaruhi oleh vokal yang sangat berkaitan dengan proses fonologis, selain adanya proses sufiksasi yang berhubungan dengan proses morfologis. Munculnya dua fenomena kebahasaan tersebut dapat sekaligus dikaji dalam proses morfofonemik dengan menggunakan pendekatan tertentu.

Word and Paradigm (WP) merupakan pendekatan berbasis kata yang dapat digunakan untuk menganalisis adanya perubahan maupun kompleksitas bunyi yang muncul pada suatu bahasa. Pada model ini kata merupakan elemen makna paling rendah dari sebuah sistem gramatikal (Blevins, 2006). Pendekatan WP mempertimbangkan pembentukan kata dalam konstruksi dan penggunaannya yang berbeda-beda (Matthews) dalam (Subiyanto, 2019). Selain itu, pembentukan kata baru dalam teori WP berasal dari kata yang telah ada sebelumnya (Aronoff, 1985). Terdapat beberapa langkah yang dapat dilakukan dalam penelitian menggunakan pendekatan Word and Paradigm ini. Langkah pertama yang dapat dilakukan, yaitu 
mendaftar seluruh leksikon atau stem dari data yang berupa kumpulan kata yang akan dikaji. Selanjutnya, kaidah pembentukan kata baru dapat ditentukan berdasarkan kategori morfosintaksisnya. Pada penelitian ini, bentuk-bentuk verba pada bahasa Turki akan dianalisis. Dari bentuk infinitif, imperfektif hingga perfektif yang termasuk dalam bentuk aspek verba, akan dianalisis perubahan bunyi yang muncul yang disebabkan oleh adanya harmonisasi vokal maupun pengasaran bunyi konsonan.

Kajian morfologis dengan menggunakan pendekatan Word and Paradigm dengan objek kajian bahasa Turki relatif jarang atau tidak begitu banyak ditemukan pembahasannya. Penelitian dengan objek bahasa Turki pada analisis morfofonemis yang dapat ditemukan, yaitu karya Pycha, Inkelas, \& Sprouse (2007) yang mengkaji tentang adanya perubahan bunyi, terutama konsonan, pada nomina-nomina dalam bahasa bahasa Turki. Dari data utama yang diambil dari TELL atau Turkish Electronic Living Lexicon, penulis mencoba untuk membuktikan hipotesis dari Wedel (2002) tentang hubungan antara tolak ukur frekuensi, kepadatan, maupun kelompok root dengan perubahan bunyi yang dihasilkan oleh penutur tunggal.

Penelitian lainnya dilakukan oleh Coltekin (2010) yang membahas fungsi TRmorph sebagai alat penganalisa morfologis dua level yang digunakan untuk membantu menganalisis bahasa Turki. TRmorph sendiri dianggap sebagai salah satu alat penganalisa yang cukup lengkap dan efektif untuk membantu menganalisis bahasa Turki yang dianggap sebagai bahasa yang cukup kompleks. Selain memperkenalkan TRmoprh sebagai alat penganalisa morfologis, dalam penelitiannya Çöltekin turut membahas dan menguraikan elemen ataupun prosesproses dalam bahasa Turki seperti harmonisasi vokalnya, perubahan bunyi-bunyi konsonannya, proses morfo fonologikalnya, maupun perubahan dan pengecualian yang ada dalam bahasa Turki, yang cukup berguna bagi penulis untuk digunakan sebagai tambahan bacaan bagi penyusunan penelitian selanjutnya.

Selain itu terdapat pula penelitian Oflazer, Göçmmen, \& Bozşahin (1994) tentang kajian proses morfofonemik, inventarisasi imbuhan, dan morfotaktik pada bahasa Turki. Karya yang berjudul 'An Outline of Turkish Morphology' tersebut sangat berguna bagi penulis karena turut mengkaji tentang proses morfofonemik seperti perubahan maupun pelesapan pada bunyi vokal maupun konsonan dalam bahasa Turki. Hal tersebut karena penulis juga akan mengkaji tentang proses morfofonemik pada bahasa Turki, namun menggunakan pendekatan yang berbeda, yaitu pendekatan Word and Paradigm.

Subiyanto (2019) dengan pendekatan Word and Paradigm mengkaji bentuk imperatif pada verba bahasa Jawa. Bahasa Jawa yang memiliki banyak imbuhan memiliki empat pemarkah imperatif, yaitu - $a$, -ana, -na, dan -en. Kompleksitas fungsi dan variasi pada imbuhan bahasa Jawa dianalisis dengan menggunakan pendekatan Word and Paradigm karena pendekatan tersebut dipandang efektif untuk menganalisis kompleksitas bunyi yang muncul pada bahasa Jawa. Penelitian ini berguna bagi penulis karena penulis juga akan menganalisis objek kajian menggunakan pendekatan yang sama.

Bram (2006) mengkaji tentang tiga pendekatan berbasis morfem dan berasis kata, yaitu pendekatan Items and Arrangement (IA), Items and Process (IP), serta Word and Paradigm (WP). Pada dua pendekatan berbasis morfem, yaitu IA dan IP, IP menjadi solusi yang lebih baik dibanding IA dalam menyelesaikan persoalan terutama pada kata yang memiliki bentuk tidak beraturan atau irregular. Setelah 
dibandingkan dengan pendekatan WP, penulis menyimpulkan bahwa dari ketiganya WP menjadi pendekatan yang paling sesuai dan paling efisien terutama berkaitan dengan morfologi infleksi. Dari beberapa penelitian yang mengungkapkan kelebihan pendekatan WP dalam menganalisis data bahasa yang mengandung kompleksitas, penulis ingin turut menerapkan pendekatan tersebut untuk menganalisis verba dalam bahasa Turki.

Seperti halnya bahasa lain, dalam bahasa Turki juga terdapat kategori gramatikal berupa tense, aspek, dan modalitas. Ketiga kategori gramatikal tersebut berpengaruh terhadap unsur verba dalam klausa. Aspek sendiri mengindikasikan tentang apakah sebuah situasi telah selesai, sedang berlangsung, atau merupakan bagian dari kebiasaan yang sifatnya berulang (Göksel \& Kerslake, 2005). Aspek dapat dikategorikan menjadi dua, yaitu perfektif dan imperfektif. Aspek perfektif dapat terlihat pada situasi yang memiliki titik mulai hingga titik akhir selesai. Pada sisi lain, aspek imperfektif merupakan situasi yang belum selesai atau masih berlangsung. Kedua aspek tersebut, dalam bahasa Turki, dapat terlihat dari kalimat dengan bentuk lampau (Göksel \& Kerslake, 2005).

Pendekatan Word and Paradigm akan digunakan untuk menganalisis proses morfofonemik pada verba bahasa Turki dilihat dari bentuk infinitif, imperfektif serta perfektifnya. Selain itu kelebihan dan kekurangan pendekatan WP yang digunakan untuk menganalisis bahasa yang bertipe aglutinatif seperti bahasa Turki juga akan turut diuraikan untuk mengetahui kesesuaian dan keefektifan pendekatan tersebut dalam menganalisis perubahan-perubahan bunyi yang muncul pada verba bahasa Turki.

\section{B. METODE}

Penelitian yang mengkaji tentang proses morfofonemik pada verba bahasa Turki dengan menggunakan pendekatan Word and Paradigm ini dianalisis dengan menggunakan metode deskriptif kualitatif. Data pada penelitian ini dikumpulkan dengan menggunakan teknik simak bebas libat cakap dan juga teknik catat (Sudaryanto, 1993). Sumber data yang digunakan pada penelitian ini, yaitu berupa video yang diambil dari beberapa platform bahasa yang mengulas tentang bahasa Turki pada media sosial YouTube. Enam video dipilih dan digunakan sebagai sumber data, yakni satu video dari platform Turkish Language, dua video dari platform Ibrahim Celiktas, dan tiga video dari platform Mehmet Seyhan ${ }^{1}$. Video-video tersebut dipilih karena mengandung data primer berupa data lisan verba bahasa Turki yang langsung dituturkan oleh penutur asli. Data primer tersebut dikumpulkan dengan teknik catat dan selanjutnya dianalisis dengan menggunakan metode padan dengan teknik dasar, yaitu teknik pilah unsur penentu (PUP), untuk kemudian di transkripsikan secara fonetis dengan panduan dari buku Laboratory Manual for Morphology and Syntax karya Merrifield, Naish, Rensch, \& Story (2003). Data yang telah ditranskripsi kemudian dikategorikan berdasarkan verba infinitif, imperfektif, dan perfektifnya. Selanjutnya data verba bahasa Turki tersebut dianalisis dengan menggunakan pendekatan $W o r d$ and Paradigm atau WP.

\footnotetext{
${ }^{1}$ Link sumber data dicantumkan pada daftar pustaka
} 


\section{PEMBAHASAN}

1. Analisis Proses Morfofonemik Verba Bahasa Turki

\section{A. Vokal Harmoni}

Salah satu kekhasan dalam bahasa Turki adalah adanya harmonisasi vokal yang memberikan pengaruh terhadap penggunaan atau penambahan akhiran. Bahasa Turki memiliki 8 bunyi vokal yang dibagi menjadi vokal tebal dan tipis. Vokal tebal terdiri dari bunyi $a, \imath, o$, dan $u$, sedangkan vokal tipis terdiri dari bunyi $e$, $i$, $\ddot{o}$, dan $\ddot{u}$. Bunyi dari vokal-vokal tersebutlah yang nantinya akan menentukan harmonisasi vokal pada akhiran yang mengikuti. Pada bentuk infinitif verba bahasa Turki terdapat dua bentuk akhiran atau sufiks dimana stem akan diikuti satu dari dua akhiran pemarkah infinitif, yaitu -mak dan -mek. Berikut beberapa bentuk verba infinitif dengan akhiran -mak dan -mek yang diambil dari kumpulan data verba bahasa Turki dalam Tabel 1.

\begin{tabular}{|c|c|c|c|}
\hline \multicolumn{2}{|c|}{$-m a k$} & \multicolumn{2}{|c|}{$-m e k$} \\
\hline 'melakukan' & [yapmak] & 'mengatakan' & [demek] \\
\hline 'tidur' & [uyumak] & 'pergi' & [gitmek] \\
\hline 'bertanya' & [sormak] & 'berjalan' & [yürümek] \\
\hline 'bekerja' & [talifmak] & 'kembali' & [dönmek] \\
\hline
\end{tabular}

Akhiran -mak digunakan ketika bunyi vokal terakhir pada stem adalah bunyi [a], [i], [o], dan [u]. Pada bunyi [yap-] terdapat bunyi vokal, yaitu [a]. Pada bunyi [uyu-] bunyi vokal yang menentukan adalah bunyi $[\mathrm{u}]$ yang kedua atau yang terakhir. Pada bunyi [sor-] bunyi vokalnya adalah [o], sedang pada bunyi [tfalif-] bunyi vokal yang menentukan adalah bunyi [i] sebagai bunyi vokal terakhir. Berbeda dengan akhiran -mak, akhiran -mek digunakan ketika bunyi vokal terakhir pada stem adalah bunyi [e], [i], [ö], dan [ü]. Pada bunyi [de-], bunyi vokalnya adalah [e], sedang pada bunyi [git-] bunyi vokalnya adalah [i]. Pada bunyi [yürü-] bunyi vokal yang menentukan adalah bunyi vokal [ü] yang terakhir, sedangkan pada bunyi [dön-], bunyi vokalnya adalah bunyi [ö].

Sebelum menentukan kaidah pembentukan kata dengan pendekatan WP, terlebih dahulu mendaftar leksikon atau stem dari bentuk verba infinitif yang ada. Dari data bentuk infinitif di bawah ini, dianalisis bentuk stem sebagai berikut.

$\begin{array}{llll}\text { Iyap/ } & \text { stem (infinitif) } \\ \text { melakukan } & \text { menggunakan } & \text { /kullan/ } \\ \text { mengatakan } & \text { /de/ } & \text { mengerti } & \text { /anla/ } \\ \text { mendengar } & \text { /dinle/ } & \text { bertanya } & \text { /sor/ } \\ \text { pergi } & \text { /git/ } & \text { bekerja } & \text { /tfalif/ } \\ \text { tahu } & \text { /bil/ } & \text { merasa } & \text { /hisset/ } \\ \text { mengambil } & \text { /al/ } & \text { mencari } & \text { /ara/ } \\ \text { tidur } & \text { /uyu/ } & \text { berbicara } & \text { /konuf/ } \\ \text { datang } & \text { Igel/ } & \text { berlari } & \text { /kof/ } \\ \text { tinggal } & \text { /kal/ } & \text { berjalan } & \text { /yürü/ } \\ \text { ingin } & \text { /iste/ } & \text { kembali } & \text { /dön/ }\end{array}$


Dari daftar stem di atas, selanjutnya dapat ditentukan kaidah pembentukan kata dengan pendekatan WP sebagai berikut.

$$
\begin{aligned}
& / \mathrm{XVa} / \rightarrow \text { /XVa-mak/ } \\
& / \mathrm{XVu} / \rightarrow \text { /XVu-mak/ } \\
& / \mathrm{XVo} / \rightarrow \text { /XVo-mak/ } \\
& / \mathrm{XVi} / \rightarrow \text { /XVi-mak/ }
\end{aligned}
$$

Stem dengan bunyi vokal terakhir [a], [u], [o], dan [i] akan mendapatkan tambahan bunyi atau akan diikuti oleh bunyi [-mak]

$$
\begin{aligned}
& \text { /XVe/ } \rightarrow \text { /XVe-mek/ } \\
& \text { /XVi/ } \rightarrow \text { /XVi-mek/ } \\
& \text { /XVü/ } \rightarrow \text { /XVü-mek/ } \\
& \text { /XVö/ } \rightarrow \text { /XVö-mek/ }
\end{aligned}
$$

Stem yang diakhiri dengan bunyi vokal [e], [i], [ü ], dan [ö] akan mendapatkan tambahan bunyi atau akan diikuti oleh bunyi [-mek].

Selain pada verba infinitif, harmonisasi bunyi vokal juga muncul pada aspek verba imperfektif orang pertama tunggal, yaitu saat bunyi vokal terakhir pada stem akan menentukan harmonisasi bunyi pada sufiks pemarkah aspek imperfektif, sebagaimana terlihat pada Tabel 2.

Perbedaan bentuk aspek verba perfektif dan imperfektif dalam bahasa Turki biasa ditemukan pada kalimat berbentuk lampau. Pada bentuk aspek imperfektif, pemarkah verba ditandai dengan sufiks -(I)yor (Göksel \& Kerslake, 2005). Bentuk (I) menandakan adanya harmonisasi bunyi vokal atau perubahan variasi bunyi vokal yang bergantung pada bunyi vokal pada root atau stemnya. Terdapat empat bentuk harmonisasi bunyi bagi pemarkah aspek imperfektif dalam bahasa Turki, yaitu [iyor], [iyor], [uyor], [üyor]. Munculnya empat variasi bunyi tersebut dipengaruhi oleh bunyi vokal pada stem seperti berikut.

(1) Ben yapıyordum

Ben yap-ıyor-du-m

1TG melakukan-IMPRF-PASS-1TG

(2) Ben biliyordum

Ben bil-iyor-du-m

1TG tahu-IMPRF-PASS-1TG

(3) Ben koşuyordum

Ben koş-uyor-du-m

1TG berlari-IMPRF-PASS-1TG

(4) Ben dönüyordum

Ben dön-üyor-du-m

1TG kembali-IMPRF-PASS-1TG 
Tabel 1. Verba Infinitif dalam Bahasa Turki

\begin{tabular}{ccc}
\hline No & Makna & Infinitif \\
\hline 1 & melakukan & yapmak \\
2 & mengatakan & demek \\
3 & mendengar & dinlemek \\
4 & pergi & gitmek \\
5 & tahu & bilmek \\
6 & mengambil & almak \\
7 & tidur & uyumak \\
8 & datang & gelmek \\
9 & tinggal & kalmak \\
10 & ingin & istemek \\
11 & menggunakan & kullanmak \\
12 & mengerti & anlamak \\
13 & bertanya & sormak \\
14 & bekerja & talifmak \\
15 & merasa & hissetmek \\
16 & mencari & aramak \\
17 & berbicara & konufmak \\
18 & berlari & kofmak \\
19 & berjalan & yürümek \\
20 & kembali & dönmek \\
\hline
\end{tabular}

Tabel 2. Verba Imperfektif dalam Bahasa Turki

\begin{tabular}{ccc}
\hline No & Makna & 1Tg (orang pertama tunggal) Imperfektif \\
\hline 1 & melakukan & yapiyordum \\
2 & mengatakan & diyordum \\
3 & mendengar & dinliyordum \\
4 & pergi & gidiyordum \\
5 & tahu & biliyordum \\
6 & mengambil & aliyordum \\
7 & tidur & uyuyordum \\
8 & datang & geliyordum \\
9 & tinggal & kaliyordum \\
10 & ingin & istiyordum \\
11 & menggunakan & kullaniyordum \\
12 & mengerti & anliyordum \\
13 & bertanya & soruyordum \\
14 & bekerja & talifyordum \\
15 & merasa & hissediyordum \\
16 & mencari & ariyordum \\
17 & berbicara & konufuyordum \\
18 & berlari & kofuyordum \\
19 & berjalan & yürüyordum \\
20 & kembali & dönüyordum \\
\hline
\end{tabular}

Stem dari [yapiyordum] adalah /yap/. Munculnya bunyi [i ] pada [iyor] dipengaruhi oleh bunyi vokal [a] pada stem. [biliyordum] memiliki stem, yaitu / bil/ di mana bunyi [i] pada [iyor] muncul karena dipengaruhi oleh bunyi vokal [i] pada [bil]. Stem dari [kofuyordum] adalah /kof/ ketika bunyi [o] pada bunyi [ko/] memicu munculnya bunyi [u] pada [uyor]. /dön/ adalah stem dari [dönüyordum], yaitu saat bunyi [ö] pada bunyi [dön] mempengaruhi munculnya bunyi [ü] pada pemarkah aspek imperfektif [üyor]. 'ben' dalam bahasa Turki merupakan bentuk pronomina personal untuk orang pertama tunggal (1TG) yang kemunculannya akan diikuti 
akhiran $-m$ yang menempel pada verba. Sedangkan $-d u$ - merupakan pemarkah lampau yang pada struktur katanya terletak setelah pemarkah aspek imperfektif dan sebelum akhiran - $m$ sebagai pemarkah pronomina personal orang pertama tunggal.

Dari keempat contoh di atas dapat diuraikan proses morfofonemik dari bentuk infinitif ke bentuk aspek imperfektif sebagai berikut.

$\begin{array}{cll}\text { Stem dari } & \text { [yapiyordum] } & : / \text { yap/ } \\ & {[\text { biliyordum }]} & : / \text { bil/ } \\ & {[\text { kofuyordum }]} & : / \text { kof/ } \\ & {[\text { dönüyordum }]} & : / \text { dön/ }\end{array}$

$/ \mathrm{XVa}+$ mak $/ \rightarrow / \mathrm{XVa}+$ iyordum $/$

$/ \mathrm{XVo}+$ mak/ $\rightarrow$ /XVo+uyordum/

Stem dengan bunyi vokal terakhir [a] dan memiliki bunyi akhiran [mak] pada bentuk infinitif akan mengalami pelesapan bunyi [mak] dan mendapatkan tambahan bunyi [iyordum] pada bentuk aspek imperfektif karena adanya harmonisasi vokal [i] pada bunyi [iyor] yang dipengaruhi oleh bunyi [a] pada stem /yap/. Sedangkan stem dengan bunyi vokal akhir [o] yang juga diikuti bunyi akhiran [mak] turut mengalami pelesapan bunyi [mak] sebagai pemarkah infinitif dan mendapatkan tambahan bunyi [uyordum] dimana harmonisasi bunyi [u] pada [uyor] dipengaruhi bunyi vokal [o] pada stem /kofl.

$/ \mathrm{XVi}+m e k / \rightarrow / \mathrm{XVi}+$ iyordum/

$/ \mathrm{XVö+mek/} \rightarrow$ /XVö+üyordum/

Stem yang memiliki bunyi vokal akhir [i] dan mendapatkan bunyi akhiran [mek] pada bentuk infinitif, akan mengalami pelesapan bunyi [mek]. Selanjutnya stem akan mengalami proses morfofonemik ketika bentuk aspek imperfektif stem mendapatkan tambahan bunyi [iyordum]. Harmonisasi bunyi vokal [i] pada bunyi [iyor] dipengaruhi oleh bunyi vokal yang sama seperti pada stem /bil/. Stem dengan bunyi vokal [ö] dan pada bentuk infinitif mendapat tambahan bunyi akhiran [mek], mengalami perubahan bunyi pada bentuk aspek imperfektif. Bunyi akhiran [mek] mengalami pelesapan dan berubah menjadi bunyi [üyordum] di mana bunyi [ü] pada [üyor] dipengaruhi oleh bunyi vokal [ö] pada stem /dön/.

\section{b. Pengasaran bunyi}

Selain harmonisasi vokal, dalam bahasa Turki juga terjadi pengasaran dan penghalusan bunyi yang biasa terjadi pada bunyi konsonan (Nuari, 2019), sebagaimana data pada Tabel 3. 
Tabel 3. Verba Perfekif dalam Bahasa Turki

\begin{tabular}{ccc}
\hline No & Makna & 1Tg (orang pertama tunggal) Perfektif \\
\hline 1 & melakukan & yaptim \\
2 & mengatakan & dedim \\
3 & mendengar & dinledim \\
4 & pergi & gittim \\
5 & tahu & bildim \\
6 & mengambil & aldim \\
7 & tidur & uyudum \\
8 & datang & geldim \\
9 & tinggal & kaldim \\
10 & ingin & istedim \\
11 & menggunakan & kullandim \\
12 & mengerti & anladim \\
13 & bertanya & sordum \\
14 & bekerja & taliftim \\
15 & merasa & hissettim \\
16 & mencari & aradim \\
17 & berbicara & konuftum \\
18 & berlari & koftum \\
19 & berjalan & yürüdüm \\
20 & kembali & döndüm \\
\hline
\end{tabular}

Dari data bahasa Turki yang diperoleh, bentuk pengasaran bunyi terjadi pada bunyi konsonan [d] pada pemarkah aspek perfektif -DI yang akan berubah menjadi bunyi [t].
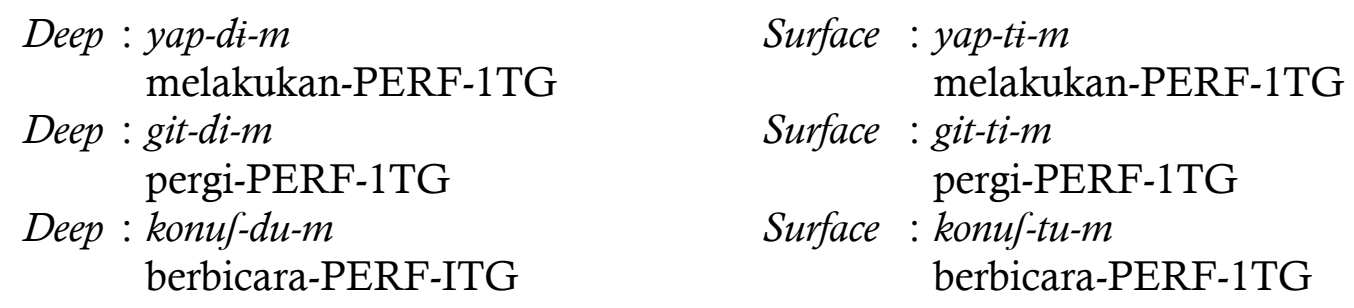

Terjadinya pengasaran bunyi pada bahasa Turki, saat bunyi [d] berubah menjadi bunyi [t] turut dipengaruhi oleh bunyi konsonan akhir pada stem. Stem dengan bunyi konsonan akhir, yaitu bunyi $[\mathrm{f}],[\mathrm{s}],[\mathrm{t}],[\mathrm{k}],[\mathrm{c}],[\mathrm{J}],[\mathrm{h}]$, dan $[\mathrm{p}]$ akan menyebabkan bunyi konsonan [d] mengasar menjadi bunyi [t] pada pemarkah aspek perfektif. Dengan pendekatan WP proses morfofonemik dari pengasaran bunyi konsonan tersebut dapat diuraikan pada kaidah pembentukan kata sebagai berikut.

$$
/ \mathrm{XCp}+\operatorname{dim} / \rightarrow / \mathrm{XCp}+t i m /
$$

Stem dengan bunyi konsonan akhir [p] menyebabkan bunyi [d] melesap dan berubah menjadi bunyi $[\mathrm{t}]$.

\section{$/ \mathrm{XCt}+\operatorname{dim} / \rightarrow / \mathrm{XCt}+$ tim $/$}

Stem yang memiliki konsonan akhir [t] membuat bunyi [d] berubah dan mengasar menjadi bunyi [t]. 


\section{$/ \mathrm{XC} \int+d u m / \rightarrow / \mathrm{XC} \int+$ tum $/$}

Stem yang diakhiri bunyi konsonan [J] membuat bunyi [d] pada struktur batin berubah menjadi bunyi [t] pada struktur lahir

\section{Efektifitas pendekatan Word and Paradigm pada analisis morfofonemik}

Subiyanto (2019) dalam penelitiannya telah mengelaborasikan bahwa teori WP merupakan sebuah pendekatan yang berbasis pada kata, yakni pada kata yang memiliki sifat-sifat tertentu seperti kata yang bersifat aglutinatif. Terdapat beberapa bahasa yang memiliki sifat aglutinatif seperti bahasa Indonesia atau bahasa Turki yang sebelumnya kerap dianalisis menggunakan teori Items and Arrangement (IA). Namun, karena batas antara kata dan morfemnya yang sangat tipis, pada bahasa Turki diperlukan adanya pendekatan yang lebih efektif untuk menguraikan kompleksitas yang muncul dalam setiap katanya. Terutama pada analisis morfofonemik yang mengkaji perubahan sekaligus pada dua sistem, yaitu morfologi dan fonologi. Pendekatan WP cukup efektif digunakan pada elaborasi proses morfofonemik yang terjadi pada verba bahasa Turki. Kompleksitas yang muncul pada bentuk infinitif, aspek imperfektif, dan perfektif pada bahasa Turki yang dipengaruhi oleh adanya harmonisasi vokal dan pengasaran bunyi konsonan dapat dijelaskan menggunakan pendekatan WP tersebut. Seperti pada contoh di bawah ini, yaitu pada bentuk aspek imperfektif untuk orang pertama tunggal atau pronomina personal.

\section{Ben kaliyordum \\ Ben kal-iyor-du-m \\ 1TG tinggal-IMPRF-PASS-1TG}

Pendekatan WP dapat digunakan untuk menganalisis proses morfofonemik yang terjadi pada contoh kata di atas ditinjau dari bentuk infinitifnya, yaitu kalmak. Pada proses morfologis, stem / kal/ yang memiliki sufiks -mak pada bentuk infinitif berubah menjadi / kal/ dengan sufiks -iyordum yang bila diuraikan lebih luas lagi terpecah menjadi sufiks $-i y o r,-d u$, dan $-m$ sebagai pemarkah imperatif, lampau, dan pronomina personal. Sedangkan pada proses fonologis, terjadinya perubahan bunyi dari bentuk infinitif ke bentuk imperfektif dipengaruhi oleh adanya harmonisasi vokal yang menjadi kekhasan dari bahasa Turki. Bunyi vokal [a] pada stem / kal/ menyebabkan munculnya bunyi yang sama, yaitu vokal [a] pada akhiran -mak pada bentuk infinitif. Bunyi tersebut akan mengalami perubahan seiring berubahnya kata ke bentuk imperfektif di mana bunyi vokal [a] pada sufiks -mak akan menjadi bunyi [i] sebagai harmonisasi vokal pada sufiks -iyor terhadap stem / kal/ yang memiliki bunyi vokal [a]. Gambaran proses morfofonemik pada contoh kata tersebut dapat ditunjukkan melalui formula sebagai berikut.

\section{$/ \mathrm{XVa}+$ mak/ $\rightarrow / \mathrm{XVa}+$ iyordum/}

Dengan teori WP, kompleksitas-kompleksitas pada bahasa Turki seperti adanya perubahan bunyi vokal dan pengasaran bunyi konsonan yang tidak dapat dianalisis menggunakan teori IA, dapat dijelaskan melalui kaidah pembentukan kata. Dari kaidah tersebut dapat diketahui pelesapan atau penambahan bunyi yang 
ada, atau pengasaran serta penghalusan bunyi yang mungkin saja muncul. Sifat aglutinatif yang dimiliki bahasa Turki dapat menyebabkan potensi sufiks yang muncul berjumlah lebih dari dua. Selain itu, dengan variasi harmonisasi bunyi yang kemungkinan berbeda-beda pula, dapat menghasilkan kaidah pembentukan kata yang cukup kompleks dan panjang, sehingga diperlukan kecermatan dalam proses penguraiannya.

\section{PENUTUP}

Penelitian yang mengkaji proses morfofonemik verba bahasa Turki dengan pendekatan Word and Paradigm ini terbagi ke dalam dua poin pembahasan. Poin pertama merupakan uraian proses morfofonemik yang dipengaruhi oleh adanya harmonisasi vokal dan pengasaran bunyi pada verba bahasa Turki. Sedangkan poin yang kedua berisi uraian pembahasan efektifitas pendekatan Word and Paradigm pada analisis morfofenemik terutama pada verba bahasa Turki. Kompleksitas dalam bahasa Turki yang menyebabkan munculnya banyak perubahan bunyi membuat penelitian ini tidak cukup jika hanya dikaji dengan menggunakan pendekatan Items and Arrangement. Sebaliknya, pendekatan Word and Paradigm dinilai lebih efektif digunakan untuk menganalisis proses morfofonemik yang muncul pada bentuk infinitif, aspek imperfektif, dan aspek perfektif dari verba bahasa Turki melalui kaidah pembentukan kata baru pada setiap bentuk dan aspek katanya.

\section{DAFTAR PUSTAKA}

Aronoff, M. (1985). Word formation in generative grammar. Cambridge: The MIT Press. Blevins, J. P. (2006). Word-based morphology. Journal of Linguistics, 42, 531-573. https://doi.org/10.1017/S0022226706004191

Booij, G. (2005). The grammar of words: An introduction to linguistic morphology. (K. Brown, E. V Clark, A. Mcmahon, J. Miller, \& L. Milroy, Eds.). New York: Oxford University Press.

Bram, B. (2012). Three models of English morphology. LLT Journal: A Journal on Language and Language Teaching Journal, 15(1), 179-185. https://doi.org/10.24071/11t.2012.150105

Celiktas, I. (2018). Learn Turkish (session-18): Simple past (affirmative) tense in Turkishgeçmiş zaman. Retrieved from https://www.youtube.com/watch?v=htmidT9inE\& $=424 \mathrm{~s}$

Celiktas, I. (2019). Learn Turkish (session-45): Verbal noun suffixes -mak,-mek/-ma,-me. Retrieved from https://www.youtube.com/watch?v=bgk6A3ozWrs\&t=378s

Coltekin, C. (2010). A freely available morphological analyzer for Turkish. In Proceedings of the 7th International Conference on Language Resources and Evaluation (LREC 2010) (pp. 820-827). Valetta, Malta: European Language Resources Association (ELRA). Retrieved from http://www.lrecconf.org/proceedings/1rec2010/pdf/109_Paper.pdf

Göksel, A., \& Kerslake, C. (2005). Turkish: A comprehensive grammar. London: Routledge.

Language, T. (2018). Turkish language grammar infinitive imperative mek mak. Retrieved from https://youtu.be/gSagX5BUmrw

Lieber, R. (2009). Introducing morphology. Cambridge: Cambridge University Press.

Merrifield, W. R., Naish, C. M., Rensch, C. R., \& Story, G. (Eds.). (2003). Laboratory 
manual for morphology and syntax (7th ed.). Dallas, Texas: SIL International.

Nuari, T. R. (2019). Kursus bahasa Turki: Endonezyam-belajar bahasa Turki. Endonezyam.

Oflazer, K., Göçmmen, E., \& Bozşahin, C. (1994). An outline of Turkish morphology (pp. 1-29).

Oktavia, W. (2019). Eskalasi Bahasa Indoglish dalam Ruang Publik Media Sosial. Diglosia: Jurnal Kajian Bahasa, Sastra, dan Pengajarannya, 2(2), 83-92. https://doi.org/10.30872/diglosia.v2i2.20

Pycha, A., Inkelas, S., \& Sprouse, R. (2007). Morphophonemics and the lexicon: A case study from Turkish. In M.-J. Sole, P. S. Beddor, \& M. Ohala (Eds.), Experimental Approaches to Phonology (pp. 369-385). Oxford: Oxford University Press.

Seyhan, M. (2013a). Online Turkish lesson basic 2 part 1. Retrieved from https://youtu.be/rlNjSkp_Ed8

Seyhan, M. (2013b). Online Turkish lesson basic 2 part 2 positive present tense. Retrieved from https://youtu.be/frfKeqP8dbY

Seyhan, M. (2015). Online Turkish lesson basic 3 part 23 geçmiş zaman simple past tense verbs. Retrieved

from https://www.youtube.com/watch?v=6GU3ysOexME\&t=21s

Subiyanto, A. (2019). A word and paradigm approach on word formations: A case study on Javanese verbs. Proceedings of International Conference on Southeast Asian Maritime World, (2019), 15-21.

Sudaryanto. (1993). Metode dan aneka teknik analisis bahasa: Pengantar penelitian wahana kebudayaan secara linguistis. Yogyakarta: Duta Wacana University Press.

Wardah, N., \& Subiyanto, A. (2019). Morphophonemic Analysis on Postpositional Affixes in Kamano Language of Papua New Guinea: An Item and Process Approach. Parole: Journal of Linguistics and Education, 9(2), 90-100. https://doi.org/10.14710/parole.v9i2.90-100

Yavuz, H., \& Balc1, A. (2011). Turkish phonology and morphology. (Z. Balpınar, Ed.). Anadolu University. 